\title{
Institutional preparation for relaxation of control over the upstream petroleum industry in China
}

\author{
Chen Shouhai* and Zhang Baosheng \\ School of Business Administration, China University of Petroleum, Beijing, 102249, China
}

\begin{abstract}
Relaxation of control over the upstream business of the petroleum industry in China is discussed. The authors suggest that a basic institutional preparation should be made before relaxing control over the upstream business, and that the institutional preparation includes at least four parts: 1) setting up the admission standards, 2) perfecting the management system of mining rights, 3) reforming the royalty and taxation system for oil and gas resources, and 4) improving the supervision and management system. Stressing the institutional preparation before relaxation of control does not mean that China could not relax control over the upstream business until the management systems are perfected, but the authors suggest that China could establish a necessary system for relaxation of control and to improve it with future practice.
\end{abstract}

Key words: Petroleum industry, upstream business, relaxation of control, institutional preparation

\section{Introduction}

With the rapid development of the national economy, the gap between the supply and demand of oil and gas in China is increasing. Many plans and measures for securing the supply of oil and gas have been reported in the literature (Liu \& Wang, 2006; Yin \& Liu, 2006; Wang and Li, 2006; Wang et al, 2006). Relaxation of control over the upstream business in China could not only ensure fair competition among various companies, but also help maximize the efficiency of domestic production of oil and gas in China (Chen, 2008). In February 2005, in Some Opinions of the State Council on Encouraging, Supporting and Guiding the Development of the Individual, Private and Non-public Ownership Economy (36 Articles regarding Non-public Economy), the State Council clearly announced that China would speed up the reform of the monopolized industries. Market competition mechanisms would be further introduced into such areas as electric power, telecommunications, railway, civil aviation, and the petroleum industry. The qualified non-public enterprises would be allowed to have rights for exploration and mining of mineral resources fairly and equally in light of the law, and private capital would be encouraged to undertake commercial exploration and production of the mineral resources. In the opinion-soliciting draft of the Energy Law, promulgated on December 1, 2007, there is also a definite stipulation that a multiple investment and property right system would be exercised in the energy field. Because the upstream business has been for a long period monopolized by three giant stateowned petroleum corporations, some scholars have voiced their opposition against the relaxation of control over the upstream business (Xing, 2005). In fact, not only monopoly

*Corresponding author. email: chenshouhai@163.com

Received January 7, 2008 enterprises worry about the relaxation of control, but also the government has no sufficient institutional preparation.

The existing petroleum resources management system in China has been formed under long-term monopoly. If the relevant institutional preparation is not synchronized with the process of relaxation of control over the upstream business, the petroleum industry would get into trouble just as the coal industry has. Coal resources are wasted and frequent accidents have taken place. To accelerate the development of the upstream sector and secure oil and gas supply, it is necessary to relax control over the upstream sector (Chen, 2008). However, corresponding institutional preparation must be made in advance, including setting up the admission standards, defining the management system of petroleum rights, reforming the taxation and royalty systems for oil and gas resources, and establishing a complete supervision and management system.

\section{Setting up admission standards}

In accordance with the provisions of the Mineral Resources Act and Regulations on Registration of Mineral Resources Exploration Block, the license system has been introduced in the upstream business in China. Only the petroleum enterprises approved by the State Council have the right to explore and develop petroleum resources. But in fact, only a few state-owned petroleum enterprises like CNPC, Sinopec, CNOOC and Yanchang Oilfield Administration Bureau have been approved. The standards for setting up a private oil enterprise have not yet been declared. Oil and gas resources are non-renewable resources, so protective production of oil and gas is needed so as to enhance the recovery rate and to maximize the effectiveness of utilization. Petroleum exploration and production is capital-intensive, technology-intensive and involves long production period 
and complicated and dangerous operations. Accidents like explosion, leakage and well blowout might result in serious environmental pollution and personal casualties. Therefore, relaxation of control over the upstream business does not mean that anyone can undertake petroleum exploration and production. Strict admission standards must be set up to ensure people with petroleum rights utilize proper methods and measures in petroleum exploration and production, and to have the capacity of fulfilling enormous social responsibilities.

It is reported that the National Development and Reform Commission of China is drafting the admission standards for permitting private companies into the upstream petroleum field (China's First Financial Daily, July, 8, 2007, page A03). Regarding what should be included in the standards, some scholars have put forward that the standards should cover the scale benchmark, environmental level, technology level, equipment capacity, etc. (Che, 2005). The authors believe that the admission standards are just the basic requirements for setting up a petroleum enterprise, but are not aimed at any specific exploration or production project. Setting up some technology or equipment benchmark does not make sense for this purpose. In the upstream sector, professional divisions have taken shape for a long time. The petroleum enterprises do not need to possess all the exploration and production technologies and equipment but to purchase professional services from the market. Halliburton and Schlumberger, for example, are the internationally renowned oil \& gas service providers. After CNPC separated its supporting businesses from its major business, the supporting businesses such as drilling, geophysical exploration etc does not legally belong to PetroChina Co. Limited.

The admission standards are just basic requirement for setting up a petroleum exploration and production enterprise, and do not need to be complicated. "Low entry threshold but strict supervision" is a trend for modern enterprise systems, and is also suitable to petroleum exploration and production enterprises. The admission standards could not be expected to serve too many functions. The standards for setting up a petroleum enterprise could include three aspects: Firstly, the managers of a petroleum enterprise ought to have a basic knowledge of petroleum exploration and production. In order to avoid blindly setting up a petroleum enterprise because of a misunderstanding of the petroleum industry and to avoid a blind command of production and management that might cause environmental pollution, destruction of resources and serious production accidents, a proper proportion of the board of directors is expected to have the management experience in oil and gas industry or to have professional knowledge of oil and gas. Secondly, a relatively high requirement for registered capital is needed. The exploration and production of oil and gas requires heavy investment and high risk. A "dry hole" can cost of millions and even tens of millions of dollars. Petroleum exploration and production involves much danger. Once an accident happens, it might cause serious environmental pollution, personal casualties and loss of property. High requirements for the registered capital could ensure that an enterprise should have corresponding investment capacity, taking risks and compensation. Thirdly, there needs to be a reliable and effective production and management system. Petroleum exploration and production is a dangerous work. Strengthening management is a good way to avoid dangers and accidents. It is far from enough for a petroleum enterprise to merely have a management system, but requiring it to have a strict reliable management system when it is set up is better than making remedies after an accident happens. The very process of establishing a management system is also favorable for the managers at all levels to deepen their understanding of petroleum exploration and production, strengthen their awareness of risks and heighten their initiative to implement the management system.

\section{Improving the management system of petroleum mining right}

Under the "state-run" system, there is no need to stress the state ownership value of oil and gas resource; there is no sharp conflict of interests between the state-owned companies. Any dispute regarding the petroleum right between them can be solved through administrative measures. However, once the control of the upstream business is relaxed, with the entry of the market bodies of different economic natures, management of the petroleum mining right ought to be assured in the following aspects, so as to embody the value of the state ownership of petroleum resources, ensure fair competitions between various companies, and to realize an effective use of the petroleum resources:

(1) Differentiating petroleum right and petroleum mining license. Petroleum right and petroleum license are conceptually different, the former refers to prospecting right and extracting right over specified mineral blocks, and the latter means the right of undertaking mining business. Any company that meets the admission standards should be granted the mining license, however, a company which owns the mining license does not consequentially acquire automatically a petroleum right in specific blocks. However, China's existing laws have not differentiated petroleum right and petroleum license. According to the Implementation Rules on Mineral Resources Law, to establish mining enterprises, it is necessary for them to have prospecting report of mineral resources, scopes of mineral area and production area, feasibility report of mining construction and design, combining mining license with specified mineral blocks. Even some scholars also consider that the mining right is equal to the mining license (Cui \& Xiao, 1998).

Mining right and mining license are obviously confused. Mining right including prospecting right and extracting right is a specific right of mineral resources ownership under the private law, and can be transferred among different bodies. The State's granting the prospecting right and extracting right, based on state ownership, is an act of exercising its private right. Mining license, as mining qualification, is a right under public law, granted only by the government. State's granting the mining license, is based on its function of economic and social management, and is an act of exercising its public right. Granting of the prospecting right and extracting right could follow a system of tendering and bidding, ensuring fair 
competition between the bidders and realizing the maximum interest of the owner. Granting the mining license should adopt a censorship system, ensuring that market players can enjoy the right of fair competition and that the upstream sector maintains healthy and orderly.

(2) Granting the mining right through a bidding process. Article 16, of the Regulations for registering to explore for mineral resources using the block system stipulates that the exploration right can be acquired through a bidding process. In foreign cooperation for production of off-shore and on-shore oil and gas, China has carried out tendering procedures to decide foreign partners. But for the domestic oil companies, due to lack of competition, the mining right is granted by the approval of the government. Under this management system, a state-owned company will be granted the mining right only if it has no conflicts with other companies in the block being tried for. Even if different petroleum companies have conflict of interest in the exploration block, the supervision department will solve it through coordination. When relaxing control over the upstream business, the number of companies bidding for mining mineral resources will increase. So will the conflict of interests. Moreover, since the companies have their own independent economic interests, it is impossible that the mining right is granted through the administrative order or coordination from the government supervision department. To ensure fair competition and to promote investment in petroleum exploration, the mining right should be granted through a bidding process.

(3) Strictly implementing the system of the exploration right utilization fees and the minimum exploration investment. At present, China has an area of about 5.5-6 million square kilometers of continental and marine sedimentary basins. Three giant state-owned petroleum corporations and the Yanchang Oilfield Administration Bureau have registered an area of 4.4 million square kilometers. After relaxing control over the upstream business, a possible problem is that the state can not show any block for invitation for bid at all and the newly established oil companies still have no opportunity for participation. In order to prevent some oil companies from registering the exploration rights while occupying the designated petroleum blocks without doing any exploration, a system of mineral exploration right utilization fee and the minimum exploration investment, which is prescribed in Regulations for registering to explore for mineral resources using the block system, must be strictly implemented. According to the rules, the exploration right utilization fee is from RMB 100 to 500 per square kilometer per year and the minimum exploration investment is from RMB 2,000 to 10,000 per square kilometer per year. But these rules have not been obeyed strictly by the stateowned petroleum companies in the past. Any block that the exploration right utilization fee has not been paid on time or the minimum exploration investment has not been made should be taken back and re-opened to new bids.

(4) Rationally dividing the petroleum exploration blocks. The petroleum exploration blocks in China are divided by $1^{\prime} \times 1^{\prime}$ in latitude and longitude as the basic unit on the theodolite. The permitted maximum register stock of each petroleum exploration project is 2,500 basic units. Because of the complexity of petroleum exploration, the strata that have been prospected but with no discovery of oil and gas are still of exploration value. The Nanpu Oilfield in the Bohai Bay Basin which was just made known in 2007, for instance, was found in the block that had been prospected by some international oil companies. In Alberta, Canada, petroleum blocks are divided not only horizontally but vertically as well in light of the difference in strata, in an attempt to implement a three-dimensional management system, so that different strata of the same block may be granted to different persons with the mining right (Zha, 1999). These management systems are good examples for China.

(5) Ensuring the integrity of petroleum reservoirs. Because petroleum resources exist in fissures of rocks underground and might displace with the change of underground pressure, petroleum development requires an overall planning and a rational arrangement of wells. And only when proper technical measures and production rate are adopted can a stable and high output be realized, consequently improving the recovery efficiency and achieving full utilization of petroleum resources. Division of petroleum mining areas only in light of the ground surface might result in such a case, that the same reservoir is assigned to different companies with mining right, leading to competitive production between these companies, and causing damage to the whole reservoir. To avoid such a case as mentioned above, Alberta, Canada takes a measure of setting a "corridor" between different blocks, while the United States takes a way of joint exploration (Lowe, 2003). These are also good examples for China.

\section{Reforming the royalty and taxation system for oil and gas resources}

Oil and gas resources taxation is characteristic of an absolute land rent and a differential land rent, both of which are the display of the rights and interests of the owner of mineral resources. At present, however, China levies $0 \%-12.5 \%$ royalty for developing marine oil and gas resources and Chinese-Foreign cooperative projects on oil and gas, and levies resources tax, mineral resources compensation fee, and special oil gain levy from the domestic petroleum companies. According to the petroleum-related regulations, tax revenues on continental petroleum resources are an income of the local government, while the tax on marine petroleum resources is an income of the central government; The mineral resources compensation fee is shared by the central government and the local government, with the ratio between the central government and province (or municipality) government being 1:1, and that between the central government and the autonomous region government being 4:6; The special oil gain levy is revenue of the central government. When China relaxes the control over the upstream business, the royalty and tax for petroleum resources could be readjusted as follows:

(1) Raising the ratio of petroleum resources tax to the sales income of oil and gas. According to the existing petroleum-related regulations, the resources tax, paid by Chinese oil companies in China, is RMB 14-30 per ton of oil 
and RMB 7-15 per $1000 \mathrm{~m}^{3}$ of natural gas; the compensation fee for mineral resources is $1 \%$ of the sales price of oil and gas; the mineral exploration right utilization fees is RMB 1,000 per square kilometer per year; the special oil gain levy is levied when the price of petroleum is over 40 US dollars per barrel, with the ratio being 20\%-40\%. The special revenue is calculated and levied on the progressive part exceeding the rated value according to the price and set rate. When the petroleum price is US \$ 40 per barrel, even for the oilfields with the best resources, the sum of the resources tax and the compensation fee for oil and gas resource only accounts for about $2 \%$ of the marketing price of oil and gas, far below the international average level, actually, transferring petroleum resources to oil companies at a low price. After relaxing the control over the upstream business, the private and even foreign companies compete with the state-owned enterprises on equal footing, inevitably calling for the same taxation system. Thus if a low resources tax is maintained, the interests of the state as a resources owner will be harmed.

(2) Raising the income of the local government. In light of the State Council's decision in 1993 on the implementation of the tax sharing system, income tax and the profit from the central enterprises belong to the central government. All three oil giants are central enterprises; therefore, the revenue of the local government from the local petroleum production includes only a share of the resources tax and the compensation fee for oil and gas resources. The resources tax and the compensation fee for oil and gas resources are levied so low, leading to a low income for the local government from the local petroleum production, accounting for only $1.5 \%$ of the marketing price of oil and gas. The low income of the local government from the local petroleum production will worsen the imbalance of development between regions, and lead to a lack of initiative of the local governments for protecting the lawful mining right of petroleum enterprises and even connivance or encouragement of mining without authorization, all of which constitute an important reason for the disorder of the petroleum exploitation. On the basis of raising the petroleum resources tax, an increase in the proportion of the local government's share means an obvious increase of the revenue from the local resources, which is helpful in encouraging the initiative of the local government for protection of lawful production.

(3) Reflecting the difference of natural resources and regulating the differential income from such resources. The cost of exploration and production of different oil and gas fields differs greatly, and the size of a reservoir, the depth of its burial, the geologic condition, the production phase, the geographical location and even the climate there, all may affect the cost of exploration and production of oil and gas. Nowadays, China exercises a Disparate Tax Rate System for resources tax with RMB 14-30 per ton, far from reflecting the difference of resources in different oil and gas fields. Some scholars suggested that a nationwide study could be conducted for the quality structure and the grade of petroleum resources and a norm of resource tax could be set differently for good resources and bad ones in a scientific and systematic manner, in view of the given conditions, geographical location, technical requirements of production, depth of burial, quality, and objective differences at different production stages and whatever (Luo, 2005; Pan, 2006). In the authors' opinion it is an impossible task to respectively set a norm of resource tax for thousands of oil and gas fields of different sizes all over the country. Besides, this will give rise to corruption in officialdom. In reforming the resources tax, we should change the old ways of attempting to evaluate the resources condition of different oil and gas fields, but establish a tax and revenue legal system of oil and gas resources with the income tax on a sliding tax rate as the core. Under the sliding tax rate, the better the resource condition, the higher the profit of the enterprise with mining-right, and a resulting higher tax rate would be adopted. Besides, in calculating the income tax, taking an enterprise into account instead of a single oilfield could encourage enterprises to invest in an oilfield with bad resource conditions.

(4) Taking into account the variation of the price of oil and gas and regulating the earning of petroleum enterprises. At present, the tax and fees on petroleum resources are levied in China either by fixed quota to unit production or by a fixed rate to the total income. This kind of tax and fees is not only relatively low as a whole but rigid as well. The special oil gain levy, which began to be collected in March 2006, plays a very limited role in regulating the earnings of oil enterprises due to too high a starting point. The rigidity of the petroleum resources tax leads to such an unpleasant and strange result that the higher the oil and gas price is, the lower the proportion of the state earnings will be; and correspondingly, the lower the oil and gas price is, the higher the proportion of the state earnings will be. The petroleum resources tax not only fails to regulate the earnings level of oil enterprises at different oil prices, but enlarges the amplitude of fluctuations of enterprises' operation with oil price. In some advanced countries, the resources tax and the income tax of enterprises are combined together, and the sliding tax rates are applied. In such a way, the higher the income of oil enterprise is, the higher the tax rate will be. The petroleum tax system with a sliding tax rate can increase the state revenue in the period of higher oil price and alleviate the enterprises' tax burden in the period of lower oil price. This is, therefore, helpful to stabilize operation of the enterprises to a certain extent.

\section{Strengthening the supervision of the upstream sector}

At present, the upstream sector of the petroleum industry in China is supervised by several departments, including the National Development and Reform Commission, the Ministry of Land and Resources, the Ministry of Finance, the Ministry of Environmental Protection and the State Administration of Work Safety. However, all these departments are general management departments, other than those that just exercise supervision of the oil industries, for they also have to undertake the onerous duty of policymaking and have a limited force to supervise the forefront of production. The current good situation in the upstream sector is, in effect, owing to the monopolized management and the self-restraint of the three oil giants, namely, China National 
Petroleum Corporation (CNPC), China National Offshore Oil Corporation (CNOOC) and China Petrochemical Corporation (Sinopec). If there is no powerful supervision organization and no reliable supervision system after relaxation of control over the upstream sector, a disordered situation like that in the coal industry would occur.

(1) Setting up an independent supervision organization. In view of the weakness in supervision of the upstream sector, both academic circles and professionals suggest that an independent supervision organization be set up in light of the principle of separating policy-making from policy implementation (Chen, 2001). For such an organization, some scholars considers it a government organization, some considers it a quasi-government organization, and still some believes that it could be a nonprofit organization independent of the governmental institutions (Zhu, 1996; Chen, 2001; Wang and Yang, 2005) This supervision organization can be financed by the government or can collect a charge for service from those supervised enterprises. Supervision covers the management of the petroleum resources, supervision of the admission of industries, finance and tax supervision, markets supervision, technical supervision, arbitration service, etc.

(2) Establishing a rational scope of supervision. Oversupervision by the government will weaken the strength of supervision. After relaxation of control over the upstream sector, if the market plays a regulating role, the government should loosen its supervision. Supervision of oil and gas price, for instance, is very necessary under a monopoly system. Once there is the competition between various production enterprises, and the price competition between domestically produced oil and gas produced at home and imports, the supervision of the price ought to be gradually loosened, letting the market, not the government, determine the price. The main duty of supervision of the upstream sector is to safeguard the interests of the state as a petroleum resources owner, to ensure fair competition between various market players, to promote an effective use of the petroleum resources, to prevent prospectors and producers from making false reports on the amount of work and the output, and to prevent the occurrence of accidents harmful to environment and personal safety in exploration and production.

(3) Rationally configuring the power and responsibility of the supervision organization, and increasing the penalties for illegal actions. Frequent accidents in the coal industry and serious pollution in different regions along with economic development make the State Administration of Work Safety and the Ministry of Environmental Protection open to criticism. One of the important reasons is that the levels of supervision personnel are not sufficient, but the most important reason is that these two government organizations have no punishment power with a deterrent effect. The way to prevent the production enterprises from fighting a guerrilla war against the supervision organization is to give these two organizations more punishment power and to increase the penalties to law-breaking actions. The stipulations in The Tax Collection and Management Act may be taken as a mirror, in light of which a tax evader must not only pay a fine of twice to five times the amount owed, but criminal sanctions will be taken against his tax evasion when the amount exceeds a prescribed limit. While the power of the supervision departments is strengthened, the responsibility of the supervisors must be also strengthened. In addition, the supervisors should be on duty by turns in fixed terms, so as to prevent possible corruption in their service.

(4) Making full use of liability insurance system. It could be stipulated that all the exploration and production enterprises must purchase a certain amount of the liability insurance against accidents in light of their exploration and production scale. Otherwise their mining right will be cancelled. After an enterprise buys insurance, the insurance company will be responsible for personal casualty, property loss and environmental damages on a certain proportion when an accident happens in exploration or production processes. Requiring an enterprise to purchase a certain amount of insurance will not lead to a remarkable increase of cost but will avoid such a case that the enterprise cannot afford compensation when an accident occurs but the government pays for it. To avoid a huge sum of compensation, the insurance company will conduct supervision over an enterprise in its exploration and production practice from another perspective and refuse insurance cover to an enterprise with great potential risks.

\section{Conclusions}

Relaxation of control over the upstream sector is a general trend, a requirement of building a market economy, a requirement of safeguarding the energy supply as well as a requirement of social fairness and justice. However, the management system for the upstream sector in China was formed under a monopoly mechanism and is suitable for the monopoly mechanism. If the control over the upstream business is relaxed blindly without a corresponding wellprepared system, disorder will occur in petroleum industry. Stressing the institutional preparation before relaxing control does not mean waiting until the systems are perfected, but is aiming to establish a necessary system for relaxation of control and to refine it in future practice.

\section{References}

Che C B, Yang H L, Li Y X, et al. The quest for the upstream marketization of China's petroleum industry. China Petroleum Enterprise. 2005. (6): 32-35 (in Chinese)

Chen L. The restructuring \& regulatory reform of the oil and gas industry in China. International Petroleum Economics. 2001. (2): 10-18 (in Chinese)

Chen S H. Analysis on interest of opening up of upstream sectors of petroleum industry. Commercial Times. 2008. (11): 94-95 (in Chinese)

Chen S H. Study on Petroleum security and opening up of upstream sectors of petroleum industry. Market Modernization. 2008. (3): 253-254 (in Chinese)

Cui J Y, Xiao K. Basic problem of the exploration right and the production right. Chinese Journal of Law. 1998. (4): 82-91 (in Chinese)

John S. Lowe. Oil and Gas Law. West Group. 2003. 29-58

Luo D K. A research on petroleum tax reform. Taxation Research. 2005. (10): 42-43 (in Chinese)

Liu Q R and Wang J Y. Scientific and technological innovation is an 
important approach to ensuring China's oil security. Petroleum Science. 2006. 3(4): 74-77

Pan J P. Current status and evolution direction of taxation system for petroleum resources. International Petroleum Economics. 2006. 14(2): 5-8 (in Chinese)

Wang G R and Li X F. China's energy security for sustainable development. Petroleum Science. 2006. 3(4): 43-45

Wang H Y and Ding H and Li C. World energy trends, security and China's options. Petroleum Science. 2006. 3(4): 31-35

Wang S S and Yang Y J, Approaches to Reform the Management System of China Petroleum Industry. Sinopec Monthly. 2005. (9): 38-39 (in
Chinese)

Xing Z H. Opening up of upstream sectors should be slow with caution. China Petrochem. 2005. (8): 32-34 (in Chinese)

Yin J P and Liu D F. Strategic thinking on developing petroleum in China. Petroleum Science. 2006. 3(4): 46-51

Zha Q H. Basis of management on oil and gas resources. Petroleum Industry Press. 1999. (8): 97-99 (in Chinese)

Zhu Q H. Improve management system of oil \& gas mining rights referring to international experience. China Geology. 1996. (10): 27-29 (in Chinese)

(Edited by Zhu Xiuqin) 